\title{
Pedagojik Formasyon Eğitimi Alan Öğrencilerin Meslek Tercihlerine İlişkin Görüşleri ${ }^{1}$
}

\author{
DOI: $10.26466 /$ opus. 677100
}

*

\author{
Gönül Sener* - Seda Gündüzalp** \\ * Dr. Öğr. Üyesi, Munzur Üniversitesi/ Sağlık Bilimleri Fakültesi, Tunceli/Türkiye \\ E-Posta: gonulsener@munzur.edu.tr ORCID: 0000-0003-3212-7703 \\ ** Dr. Öğr. Üyesi, Munzur Üniversitesi/ Pertek Sakine Genç MYO, Tunceli/Türkiye \\ E-Posta: sedagunduzalp@munzur.edu.tr ORCID: 0000-0003-3546-5644
}

\section{Öz}

Geçmişten günümüze kadar popülaritesi devam eden mesleklerden biri olan öğretmenlik, bir yandan sevgi ve gönül işi olması diğer yandan da ülkelerin geleceğgi ve toplumların gelişiminde kritik bir role sahip olması sebebiyle meslek olarak tercih edilme nedenleri arasında önemli bir yere sahip olduğu belirtilmektedir. Bireyin kişiliğine uygun meslek tercihinde bulunması, işini severek yapması ve işine bağhllığında önemli bir etkiye sahiptir. Bu nedenle doğru meslek seçimi ve süreçleri konusunda bilgi sahibi olmak kişinin gelecekteki yaşam biçiminin belirlenmesini etkileyecektir. Araştırmanın amacı öğretmen olma niyetiyle formasyon eğitimi alan öğrencilerin seçtikleri öğretmenlik mesleğine ilişkin görüşlerini belirlemektir. Çalışma, nitel araştırma yöntemlerinden olgubilim deseni ile gerçekleştirilmiştir. 20172018 eğitim öğretim yılında Ĕ̆itim Bilimleri Bölümü'nde formasyon eğitimi alan 60 öğrenci çalışma grubu olarak belirlenmiştir. Çalışma verilerinin toplanması görüşme formuyla sağlanmıştır. Öğretmen adaylarının görüşleri dikkate alınarak toplanan verilerin analiz edilmesinde içerik analizi yöntemi kullanılmıştır. Araştırmanın sonucunda; öğretmen adayları sıklıkla ilk tercihlerinin yine öğretmenlikten yana olduğu yönünde görüş bildirirken bu görüşü sırasıyla doktor, sosyolog, sanatçı, hukukçu, mühendis, gazeteci, yazar ve psikolog izlemiştir. Öğretmenlik, meslek tercihleri arasında ilk sirada olan öğrenciler bu mesleği seçmede; bir şeyler öğretmenin verdiği hazzı yaşamak, meslek sevgisi, daha iyi bir nesil yetiştirmek, mesleğin kutsallı̆̆l, çocuk sevgisi, bütün meslek mensupların öğretmenlerin yetiştirmesi,

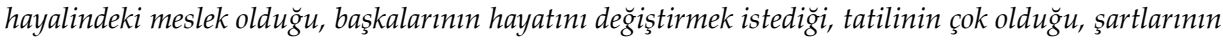
iyi olduğu ve çocukları geleceğe hazırlamak gibi birçok nedeni sıralamışlardır.

Anahtar Kelimeler: Öğretmen adayı, meslek tercihi, öğretmenlik

\footnotetext{
${ }^{1}$ Bu çalışma 10-12 Mayıs 2018 tarihleri arasında yapılan "13. Uluslararası Eğitim Yönetimi Kongresinde" sözlü bildiri olarak sunulmuştur.
} 


\title{
Opinions on the Taking Pedagogical Formation Education Students of the Job Preferences
}

\begin{abstract}
Teaching, which is one of the most popular occupations from the past to the present, has an important place among the reasons why it is preferred as a profession because it has a love and heart work on the one hand and a critical role in the future of countries and the development of societies. Choosing a profession appropriate for the personality of the individual to do his job lovingly has an important effect on his commitment to the job. Therefore, knowledge of the right career choice and processes will affect the determination of a person's future lifestyle. The aim of the research is to determine the opinions of the students who take the formation education with the intention of becoming a teacher. The study was carried out with a scientific pattern, one of the qualitative research methods. In the 2017-2018 academic year, 60 students in the Department of Educational Sciences were identified as study groups. The collection of the study data was provided by the interview form. Content analysis method used in analyzing the data collected by taking into consideration the opinions of prospective teachers. As a result of the research; pre-service teachers frequently commented on the fact that their first choice was in favor of teaching, and followed this with the doctors, sociologists, artists, lawyers, engineers, journalists, writers and psychologists. Students who are in the first place among the preferences of teaching, profession, choosing this profession; to experience the pleasure of the teacher, to love the profession, to raise a better generation, to love the profession, to love children, to train teachers of all professions, to be a profession in their dreams, to want to change the lives of others, to have a lot of holiday, to have a good time and to prepare the children for the future. the reasons are listed.
\end{abstract}

Keywords: Candidate teacher, job choice, teaching 


\section{Giriş}

Bir meslek sahibi olma ihtiyacı, her bireyin dünyaya gelip büyüdüğü toplumda yaşamını devam ettirebilmesi aynı zamanda kendini gerçekleştirebilmesi için zorunludur (Yüksel Şahin ve Hotaman, 2009). Kendini gerçekleştirme konusu bireyin hayatındaki temel işlevlerden biridir. Bu işlev kişinin amacına ulaşması, potansiyelinin farkına varması, kişisel tatmin, kişisel başarı ve bilimsel buluşları tanımlanır (Kuzgun, 1985; Maslow, 1943). Kişinin icra ettiği meslek, onun yaşamında geniş bir yer tutan ve yaşam kalitesini etkileyen önemli bir unsurdur. Kendine uygun olan bir mesleği seçmesi, mesleğine karşı tutumlarının olumlu olması hem kendi hem de başkalarının mutluluğu ve çalışma verimi açısından önemlidir (Çelik ve Üzmez, 2014, s. 95). Meslek kavramı, kişinin kendini gerçekleştirmesi, bireysel gelişimini sağlaması, toplum yapısı içerisinde kendini tanıması ve görünür kılmasında etkili bir faktör olarak bilinmektedir (Elchardus ve Smiths, 2008; İlhan, 2008; Sar1kaya ve Khorshid, 2009; Ünsar, Akgün Kostak, Kurt ve Erol, 2011). Kavramsal olarak meslek, TDK sözlügünde, "belli bir eğitim ile kazanılan sistemli bilgi ve becerilere dayalı, insanlara yararlı mal üretmek, hizmet vermek ve karşılığında para kazanmak için yapılan, kuralları belirlenmiş iş" olarak tanimlanmaktadır (www.tdk.gov.tr).

Bireyin kişiliğine uygun meslek tercihinde bulunması işini severek yapması işine bağlılığında önemli bir etkiye sahiptir. Bu nedenle doğru meslek seçimi ve süreçleri konusunda bilgi sahibi olmak kişinin gelecekteki yaşam biçiminin belirlenmesini etkileyecektir. Bu olmadığı taktirde kişi sevmediği, kendisine uygun olmayan mesleği seçecek ve yaptığ iş işkenceye dönüşecektir. Bu nedenle meslek tercihi, kişinin gelişim süreci olarak meslek seçimini, gelişigüzel bir anlık kararı sonucu değil, hayatı süresince oluşan ve gelişen, vazgeçilmez olan davranış örüntüleri olarak görülmelidir (Polly ve Jimmy, 2002). Meslek seçimi insanın hayatında vereceği en önemli kararlardan biridir. Çünkü insanlar hayatlarının büyük bir kısmını yaptıkları işin başında geçirmektedir. Bireylerin meslek tercihi gelir, statü, çevre, yetenek, olanaklar ve kişilik gibi pek çok değişkenden etkilenmektedir (Püsküllüoğlu, 1986, akt. Hotaman, 2011). Genel olarak bakıldığında meslek seçimini etkileyen çeşitli faktörler bulunmaktadır. Bu faktörler; bireyin karar sürecinde etkisi altında kaldığı değer yargısı, ilgi ve inançları, mevcut bilgi birikimi, bireyin bu kararında mesleğe yönelik olarak duyduğu ilgi, sahip olduğu değerler ve elde 
edeceği tatmin gibi faktörle birlikte kişisel özellikleridir (Tokar, Fisher ve Subich, 1998).

Literatürde mesleklere yönelim ve yükseköğretim kurumlarının seçimine yönelik değişik kuramsal modeller mevcuttur. Bu modeller; eğitim öğretim sürecinin başından itibaren bireysel ilgi ve yetenekler ile bunlar arasındaki uyuma, bireyin gereksinmelerine, bireyin çevresiyle olan etkileşimine, kimlik gelişimine, kişilik özelliklerine odaklanmış, iş gücünün mesleklere doğru akışını ekonomik açıdan değerlendirmişler. (Blau, Gustad, Jessor, Parnes ve Wilcock, 1956; Ginzberg, Ginsburg, Axelrad ve Herma, 1951; Holland, 1959, 1997; Roe, 1954, 1957; Super, 1957; Tiedeman ve O'Hara, 1963).

Alan yazında meslek seçimi ile ilgili çalışmalar incelendiğinde; bireyin icra ettiği mesleğinden duygusal anlamda tatmin sağlayamaması ve mesleğe olan bağlılığının düşük olması mesleği bırakmada diğer tatmin ve bağlılık faktörlerine kıyasla daha etkili olabildiği sonucuna ulaşılmıştır (Arıkan Saltık, Avcı ve Kaya, 2016). Wildes (2004) de bireylerin sahip olduğu mesleki alg1 ve mesleğe yönelik tutumu ile mesleği sürdürme ve işten ayrılma niyeti arasında önemli düzeyde ilişki olduğu sonucuna ulaşmıştır. Öte yandan çalışanların mesleğinin gerektirdikleri ile kendi birikimleri ve uzmanlığı, ilgileri ve sahip olduğu değerlerinin uyumlu olması ve mesleğe yönelik sosyal statü algılarının yüksek düzeyde olması mesleki bağlılıkları ile doğru orantılı olarak artacağ1 (Carlesss, 2005; Edwards, 1991; Ehrahrt ve Makransky, 2007; Goulet ve Singh, 2002; Saks ve Ashfort, 1997), birey-iş uyumunun (Chellen ve Nonkoo, 2010; Edwads, 1991; Erdoğan, 1990, s. 30; Wildes, 2004) ve mesleğe ilişkin sosyal statü algısının (Çakır, 2001; Gündüz, 2005; Hall, 1969) ön planda yer aldığı ilgili çalışmalarla ortaya konulmuştur.

Geçmişten günümüze kadar popülaritesi devam eden mesleklerden biri olan öğretmenlik, bir yandan sevgi ve gönül işi olması diğer yandan da ülkelerin geleceği ve toplumların gelişiminde kritik bir role sahip olması sebebiyle meslek olarak tercih edilme nedenleri arasında önemli bir yere sahip olduğu belirtilmektedir (Bishay, 1996; Ekici, 2015; Kızıltaş, Harmatov ve Sarıçam, 2012). Yapılan bir çalışmada, öğrencilerin öğretmenlik mesleğini seçmelerinde mesleğini kendi özelliklerine uygun görmeleri, sevmeleri, öğretmenlik yaparak mutlu olacaklarına inanmaları ve ebeveynlerinin istekleri neden olarak gösterilmektedirler (Şahin, 2011). Öğretmenlik mesleğini tercih eden adayların öğretmenlik mesleğine ilişkin mesleki bilgi (alan bilgisi, alan eği- 
timi bilgisi, mevzuat bilgisi), mesleki beceri (eğitim öğretimi planlama, öğrenme ortamları oluşturma, öğretme ve öğrenme sürecini yönetme, ölçme ve değerlendirme), tutum ve değerlere (milli, manevi ve evrensel değerler, öğrenciye yaklaşım, iletişim ve işbirliği, kişisel ve mesleki gelişim) sahip olmaları (MEB, 2017), liderlik gücünü ve becerilerini ortaya koymaları gerekmektedir (Gündüzalp ve Şener, 2018). Bu niteliklere ulaşabilmek için öğretmen adaylarında yüksek öğrenim görme şartı aranmaktadır.

Ülkemizde öğretmenlik mesleği, yakın geçmişe kadar daha çok saygı duyulan bir meslek durumundaydı. Ancak, son yıllarda öğretmenlik mesleğinin saygınlığına karşılık gelen toplumsal görüş hissedilir derecede azalmaya başlamıştır. Bunun yanında ataması yapılan öğretmenlerin bir kısmının sözleşmeli atanması ve belli bir süre sonra kadroya alınması öğretmen atama ve istihdamında karmaşa yaratmaktadır. Bu durum hem halen sözleşmeli çalışan öğretmenler hem de öğretmen adayları için önemli bir sorun olma özelliğini korumaktadır (Şahin, 2011). Ayrıca verilen formasyon eğitimleri ile öğretmen olma isteğiyle bekleyen işsizler ordusunun var olması öğretmenlik mesleğini seçenlerin bakış açısını ortaya koymayı önemi kılmaktadır. Bu noktadan hareketle, araştırmanın amacı öğretmen olma niyetiyle pedagojik formasyon eğitimi alan öğrencilerin seçtikleri öğretmenlik mesleğine ilişkin görüşlerini belirlemektir.

\section{Yöntem}

$\mathrm{Bu}$ araştırma, nitel paradigma içerisinde değerlendirilen olgubilim (fenomenoloji) deseni ile şekillendirilmiştir. Olgubilim farkında olduğumuz ancak tam olarak anlam veremediğimiz olguları araştırmamıza yardımcı olur (Yıldırım ve Şimşek, 2011). Olgubilim araştırmalarda olgunun oluşturulma boyutları belli aşamalarda gerçekleştirilmektedir. Ersoy (2016), bu aşamaları aşağıdaki gibi sıralamıştır:

1. Fenomen (olgu) ya da deneyimi tanımlama,

2. Sabit temaları belirleme

3. Belirlenen temalara ilişkin çarpıcı yansımalar oluşturma

4. Yansimaları temalarla betimleme 


\section{Çalışma Grubu}

Araştırmanın çalışma grubunun belirlenmesinde amaçlı örnekleme yöntemi içinde yer alan tipik örnekleme yöntemi kullanılmıştır. 2017-2018 eğitim öğretim yılında Eğitim Bilimleri Bölümü'nde formasyon öğrenimi gören 60 öğrenci çalışma grubu olarak belirlenmiştir. Tipik örnekleme; örneklemin araştırma problemi ile ilgili olarak evrende yer alan çok sayıdaki durumdan tipik olan biriyle oluşturulmasıdır (Büyüköztürk, Kılıç Çakmak, Akgün, Karadeniz ve Demirel, 2008). Bu yöntemin seçilmesindeki neden ise incelenen konuyu en iyi yansıtacak elemanların seçimini öngörmesidir. Çalışma grubunun demografik özelliklerine ilişkin frekans ve yüzde dağılımları Tablo 1'de gösterilmiştir.

Tablo 1. çalışma grubunun demografik özelliklerine ilişkin frekans ve yüzde dağılımları

\begin{tabular}{|c|c|c|c|c|c|c|c|c|c|c|}
\hline Değişkenl & & 1 & 2 & 3 & 4 & 5 & 6 & 7 & 8 & $\begin{array}{l}\text { Top } \\
\text { lam }\end{array}$ \\
\hline \multirow{3}{*}{ Cinsiyet } & & Kadın & Erkek & & & & & & & \\
\hline & $\mathrm{N}$ & 43 & 17 & & & & & & & 60 \\
\hline & $\%$ & 71.67 & 28.33 & & & & & & & 100 \\
\hline \multirow{3}{*}{ Bölüm } & & Tarih & $\begin{array}{l}\text { Coğ- } \\
\text { rafya }\end{array}$ & TDE & $\begin{array}{l}\text { Fel- } \\
\text { sefe }\end{array}$ & $\begin{array}{l}\text { Kamu } \\
\text { Yön. }\end{array}$ & $\begin{array}{l}\text { Yaşa- } \\
\text { yan } \\
\text { Diller }\end{array}$ & $\begin{array}{l}\text { Sağ- } \\
\text { lık }\end{array}$ & Gazetecilik & - \\
\hline & $\mathrm{N}$ & 12 & 11 & 11 & 9 & 8 & 4 & 3 & 2 & 60 \\
\hline & $\%$ & 20 & 18.33 & 18.33 & 15 & 13.34 & 6.66 & 5 & 3.34 & 100 \\
\hline \multirow{3}{*}{ Yaş } & & $20-25$ & $26-30$ & $31+.$. & & & & & & - \\
\hline & $\mathrm{N}$ & 51 & 4 & 5 & & & & & & 60 \\
\hline & $\%$ & 85 & 6.66 & 8.34 & & & & & & 100 \\
\hline
\end{tabular}

\section{Verilerin Toplanmast}

Çalışma verilerinin toplanması görüşme formuyla sağlanmıştır. Hazırlanan görüşme formu araştırmanın amacına uygun ve alan yazın derinlemesine incelenerek geliştirilmiştir. Öğretmen adaylarının öğretmen olma niyetiyle formasyon eğitimi alan öğrencilerin seçtikleri öğretmenlik mesleğine ilişkin görüşleri belirlemeye dönük iki şıktan oluşan bir adet açık uçlu sorunun yer aldığı görüşme formu hazırlanmıştır. Kapsam ve görünüş geçerliği için uzman görüşü alınmış bu doğrultuda form üzerinde öngörülen değişiklikler yapılmıştır. Görüşme formunun anlaşılırlığını belirlemek üzere beş öğrenciye ön 
uygulama yapılmıştır. Yapılan uygulamanın ardından dil yapısı tekrar gözden geçirilen yarı yapılandırılmış form ana uygulama için hazır duruma getirilmiştir. Görüşleri alınmak üzere öğretmen adaylarına aşağıdaki sorular sorulmuştur:

a) Meslek seçiminde mevcut alternatifleriniz arasında seçim yapma imkânınız olsaydı ilk tercihiniz ne olurdu?

b) Öğretmenlik mesleği olurdu, çünkü

c) Diğer (ne olduğunu yazınız.) mesleği olurdu, çünkü

Çalışma grubu içinde yer alan öğretmen adaylarına görüşme formu önceden verilerek incelemeleri istenmiş, gerekli açıklamalar yapılarak formların doldurulması sağlanmıştır. Veriler Şubat-Mayıs 2018 tarihleri arasında toplanmıştır. Her bir görüşme ortalama 15 dakika, olarak belirlenmiştir. Elde edilen formlar araştırma için temel veri seti olarak kabul edilmiştir.

\section{Verilerin Analizi}

Öğretmen adaylarının görüşleri dikkate alınarak toplanan verilerin analiz edilmesinde araştırmanın amacına uygunluğundan dolayı içerik analizi yöntemi kullanılmıştır. İçerik analizi aşamalarını Robson (2015); veri setindeki bir ya da daha fazla parçasını betimlemek ve ilişkilendirmek amaciyla kodlama, kodları gruplandırılarak küçük sayıda kategorilere ayırma ve ilişkili olduğu düşünülen kategorilerle temaların uyumunu belirleme şeklinde ifade etmektedir.

$\mathrm{Bu}$ araştırma da ulaşılan verilerin kodlanması, temaların belirlenmesi, kategorilerin oluşturulup uygun temalara yerleştirilmesi, bulguların ortaya ç1karılması ve yorumlanması olarak dört aşamada analiz edilmiştir. Kodlama süreci ile genel düzeyde görüşleri açıklayabilen ve kodları belirli alt temalar altında toplayabilen temalar ortaya çıarılabilmiştir. Çalışmada ilk olarak öğretmen adaylarının görüşme formuna verdikleri cevaplar incelenmiş ve öğretmen adaylarından toplanan verilerin hepsi (60 adet form) geçerli olarak kabul edilmiştir. Daha sonra bu veriler üzerinden analizler yapılmıştır. 60 formdan her birine sayı numaraları kodlanarak Word belgesine aktarılmış ve cevaplar veri analiz programında çözümlenmeye hazır hale getirilmiştir. Elektronik ortamda yer alan veriler satır satır okunarak önemli kodlar ve boyutlar tespit edilmeye çalışılmıştır. Katılımcılar ÖA:1, ÖA:2, ÖA:3... şeklinde 
kodlanmıştır. Araştırmanın güvenirliğini sağlamak için Miles ve Heberman'ın (1994) geliştirdiği aşağıdaki formül kullanılmıştır.

$$
\text { UzlaşmaYüzdesi }=\frac{\text { GörüşBirliği }(\mathrm{Na})}{\text { GörüşBirliği }(\mathrm{Na})+\text { GörüşAyrılığı }} 100
$$

Nitel araştırmalarda, araştırmacı ve uzman değerlendirmeleri sonucunda elde edilen uyumun \%90 ve üzeri olduğu durumlarda araştırmanın güvenirliği sağlanmış kabul edilmektedir. Bu doğrultuda değerlendirme yapması istenen uzman on ifadeyi araştırmacılardan farklı bir kategoride uygun bulmuştur. Böylece yapılan hesaplamalarla araştırmanın güvenirliği; $\mathrm{P}=161 /(161+10) \mathrm{X} 100=\% 94$ olarak bulunmuş ve güvenirlik sağlanmıştır.

\section{Bulgular}

Öğretmen olma niyetiyle formasyon eğitimi alan öğrencilerin seçtikleri öğretmenlik mesleğine ilişkin görüşlerini belirlemek için yapılan bu çalışmada, öğrenciler öğretmenlik mesleğinin dışında 8 farklı mesleği kendilerine daha uygun görmüşlerdir. Öğrenciler tarafından kendilerine uygun olan meslekler frekans değerleriyle Şekil 1'de gösterilmiştir.

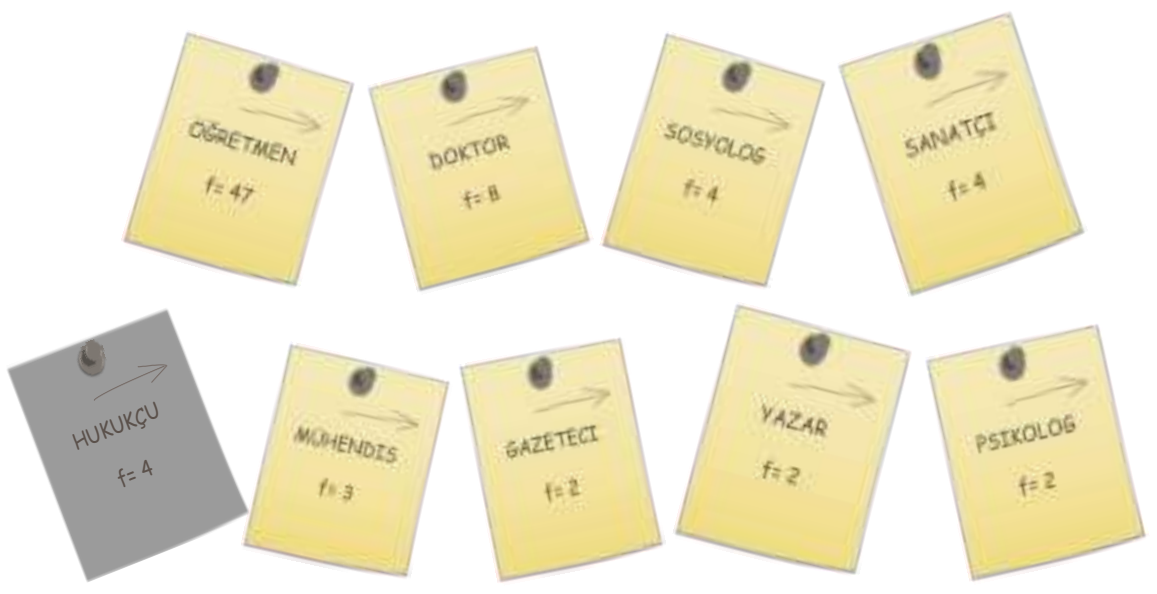

Şekil 1. Meslek seçimine ilişkin öğrenci görüşleri 
Öğrencilere sorulan "Meslek seçiminde mevcut alternatifler arasında seçim yapma imkanınız olsaydı ilk tercihim..... olurdu" sorusuna ilişkin öğrenciler çoğunlukla ilk tercihlerinin yine öğretmenlikten yana olduğunu görüş olarak bildirmişlerdir. Bu görüşü sırasıyla doktor, sosyolog, sanatçı, hukukçu, mühendis, gazeteci, yazar ve psikolog izlemiştir. Bu durum çoğunlukla öğrencilerin doğru yerde olduğunu göstermektedir. Kendine uygun mesleği bulan öğrencilerin meslek yaşamlarında daha başarılı olacakları umulmaktadır. Dolayısıyla yeni nesil yetiştirme misyonunu yüklenen öğretmenlik, zoraki yapılacak bir meslek değildir. Sıklıkla tercihler arasında yer alan öğretmenlik mesleğine ilişkin frekanslar ve tercih nedenleri Şekil 2'de sunulmuştur.

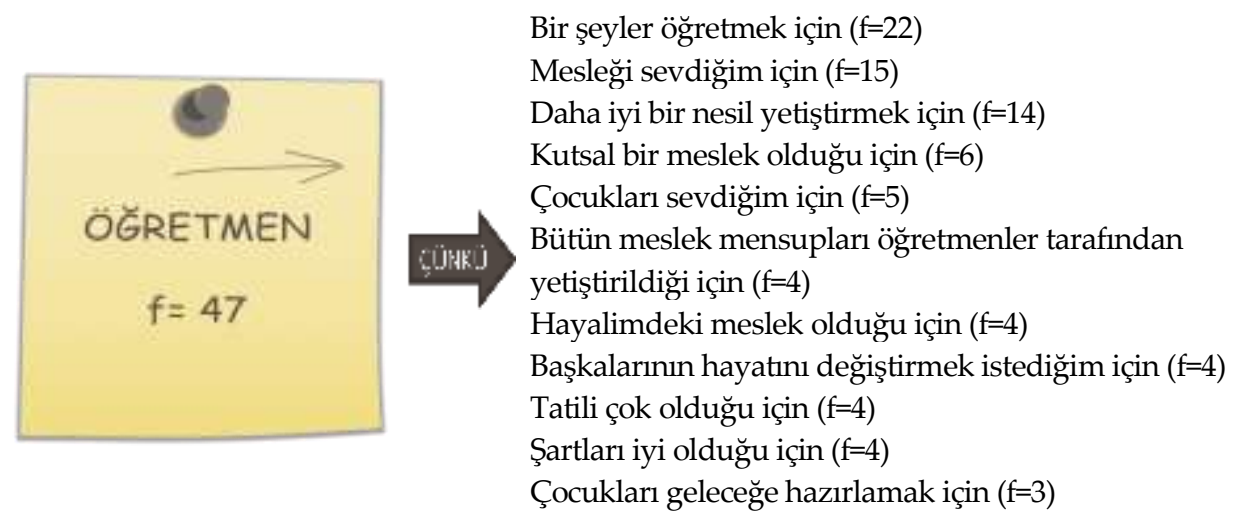

Şekil 2. Meslek seçimine ilişkin öğrenci görüşleri (Öğretmen)

Öğretmenlik meslek tercihleri arasında ilk sırada olan öğrenciler bu mesleği seçmede; bir şeyler öğretmenin verdiği hazzı yaşamak, meslek sevgisi, daha iyi bir nesil yetiştirmek, mesleğin kutsallığı, çocuk sevgisi, bütün meslek mensuplarını öğretmenlerin yetiştirmesi, hayalindeki meslek olduğu, başkalarının hayatını değiştirmek istediği, tatilinin çok olduğu, şartlarının iyi olduğu ve çocukları geleceğe hazırlamak gibi birçok neden sıralamışlardır. Meslek seçiminde tercihler arasına öğretmenlikten sonra en çok yer verilen 
doktorluk mesleğine ilişkin frekanslar ve tercih nedenleri Şekil 3'te verilmiştir.

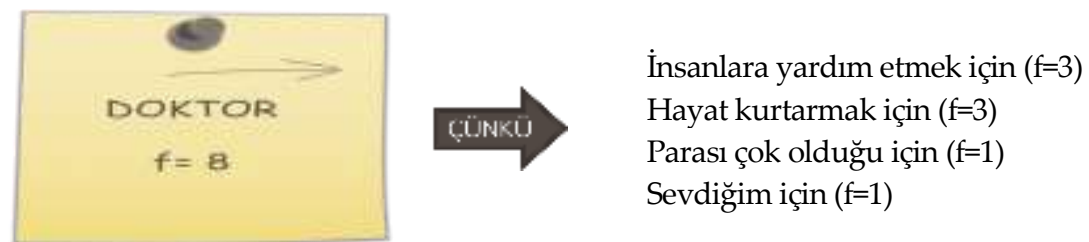

Şekil 3. Meslek seçimine ilişkin öğrenci görüşleri (Doktor)

Doktorluk meslek seçiminde ilk sırada olan öğrenciler bu mesleği seçme nedenleri olarak; insanlara yardım etmek, hayat kurtarmak, parasının çok olması ve sevdiği için bu mesleği yapmak istemesi görüşlerine yer vermişlerdir. Gerçekten de toplumumuzda doktorluk mesleği kazanılması ve eğitimi zor olan meslekler arasındadır ve popülaritesi devam etmektedir. Tercihler arasında yer alan mesleklerden biri de hukuktur. Bu mesleğe ilişkin frekanslar ve tercih nedenleri Şekil 4'te gösterilmiştir.
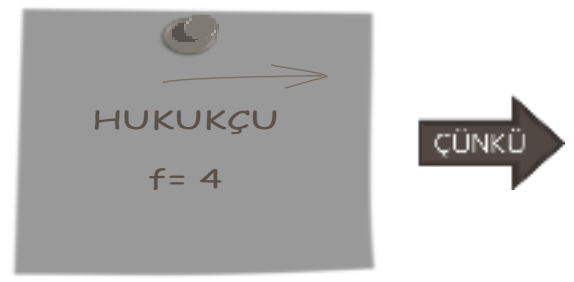

Adaleti sağlamak için ( $\mathrm{f}=2)$

Hayalimdeki meslek olduğu için ( $\mathrm{f}=2$ )

Şekil 4. Meslek seçimine ilişkin öğrenci görüşleri (Hukukçu)

Hukukçu olmak meslek tercihleri arasında ilk sırada olan öğrenciler bu mesleği seçme nedenleri olarak; adaleti sağlamak ve hayalindeki meslek görüşlerine yer vermişlerdir. Bireylerin kendini gerçekleştirebilmeleri için doğru meslek seçimleri önem taşımaktadır. Doğruluğu ve adaleti önceleyen kişilerin bu meslek grubunda yer alması toplumun geleceği açısından önem arz etmektedir. Tercihler arasında yer alan bir diğer meslek sosyologdur. Sosyolog mesleğine ilişkin frekanslar ve tercih nedenleri Şekil 5 'te yer almaktadir. 


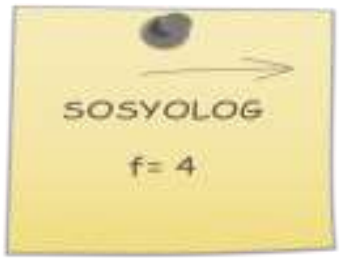

Topluma ve toplumsal sorunlara

ÇÜNKÜ duyarlı olduğum için ( $\mathrm{f}=3$ )

Kendi branşım olduğu için (f=1)

Şekil 5. Meslek seçimine ilişkin öğrenci görüşleri (Sosyolog)

Sosyolog olmak meslek tercihleri arasında ilk sırada yer alan öğrenciler topluma ve toplumsal sorunlara duyarlı ve kendi branşı olmasını mesleği seçme gerekçesi olarak göstermişlerdir. Toplumsal duyarlılığın ön planda olduğu sosyolog mesleğini tercihleri arasında gösteren öğrencilerin bu mesleği yerine getirirken mesleki doyum yaşamaları ve mesleklerinde başarılı olmaları kaçınılmazdır. Tercihler arasında gösterilen önemli mesleklerden biri de sanatçıdır. Bu mesleğe ilişkin frekanslar ve tercih nedenleri Şekil 6'da sunulmuştur.
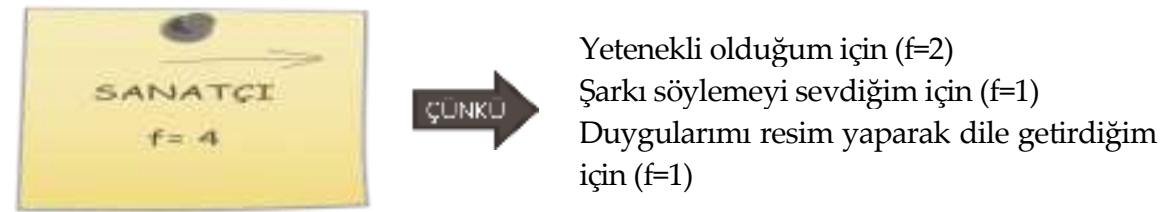

Şekil 6. Meslek seçimine ilişkin öğrenci görüşleri (Sanatçı)

Sanatçı olmak meslek tercihleri arasında ilk sırada yer alan öğrenciler bu mesleği seçme nedenleri olarak; yetenekli olmak, şarkı söylemeyi sevmek ve duygularını resim yaparak dile getirmek gibi gerekçeleri sıralamışlardır. Toplumuzda yeteneklerinin peşinden koşmak isteyen ancak erken yaşlarda aileler tarafından engellenen, farklı meslek gruplarına yönlendirilen çocukların olduğuna hepimiz şahit olmuşuzdur. Bunun yanında yeteneklerini meslek olarak değil de hobi olarak gösteren, ailesi istediği için başladığı okulunu yarım bırakıp yeteneklerine dönen bireylerin varlığından hepimiz haberdar olmuşuzdur. Tercihler arasında gösterilen bir diğer meslek mühendistir. Bu mesleğe ilişkin frekanslar ve tercih nedenleri Şekil 7'de yer almaktadır. 

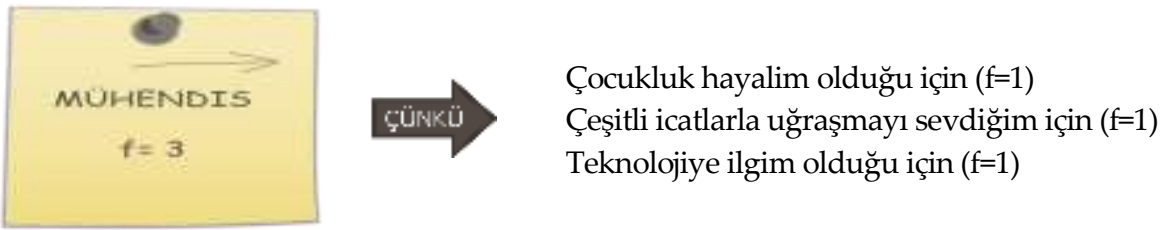

Şekil 7. Meslek seçimine ilişkin öğrenci görüşleri (Mühendis)

Mühendis olmak meslek tercihleri arasında ilk sırada yer alan öğrenciler bu mesleği seçme nedenleri olarak; çocukluk hayalinin olması, çeşitli icatlarla uğraşmayı sevmesi ve teknolojiye ilgisinin olmasını gerekçe olarak göstermişlerdir. Geçmişte popülaritesi yüksek olan mesleklerden biri olarak görülen mühendislik günümüzde popülaritesi azalmaya yüz tutmuş mesleklerden biri durumuna gelmiştir. Öğrenciler içinde azınlıkta da olsa küçük bir grubun tercihlerinde ilk sırada gazetecilik mesleği yer almaktadır. Bu mesleğe ilişkin frekanslar ve tercih nedenleri Şekil 8'de sunulmuştur.
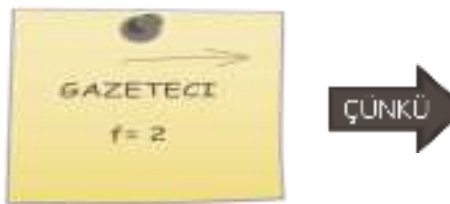

Hayalimdeki meslek olduğu için ( $\mathrm{f}=1)$

Doğru ve gerçekleri dile getirmek için ( $\mathrm{f}=1)$

Şekil 8. Meslek seçimine ilişkin öğrenci görüşleri (Gazeteci)

Gazeteci olmak meslek tercihleri arasında ilk sırada yer alan öğrenciler bu mesleği seçme nedenleri olarak; hayalindeki meslek olduğu, doğru ve gerçekleri dile getirmek istemesi bu mesleği seçmede gerekçe olarak belirtilmiştir. Yine öğrenciler içinde küçük bir grubun tercihlerinde ilk sırada yer alan mesleğin yazarlık olduğu görülmektedir. Bu mesleğe ilişkin frekanslar ve tercih nedenleri Şekil 9'da gösterilmiştir.
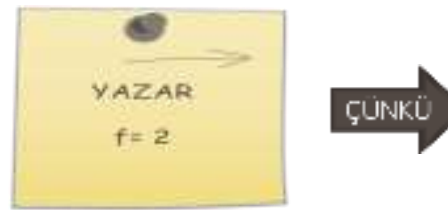

Hayalimdeki meslek olduğu için ( $\mathrm{f}=1$ )

Yazmayı sevdiğim için ( $\mathrm{f}=1)$

Şekil 9. Meslek seçimine ilişkin öğrenci görüşleri (Yazar) 
Yazar olmak meslek tercihleri arasında ilk sırada yer alan öğrenciler bu mesleği seçme nedenleri olarak; hayalindeki meslek olduğu ve yazmayı sevmesi gerekçe olarak gösterilmiştir. Tercih sıralamasında yine az görüş olan diğer meslek ise psikologdur. Bu mesleğe ilişkin frekanslar ve tercih nedenleri Şekil 10'da gösterilmiştir.
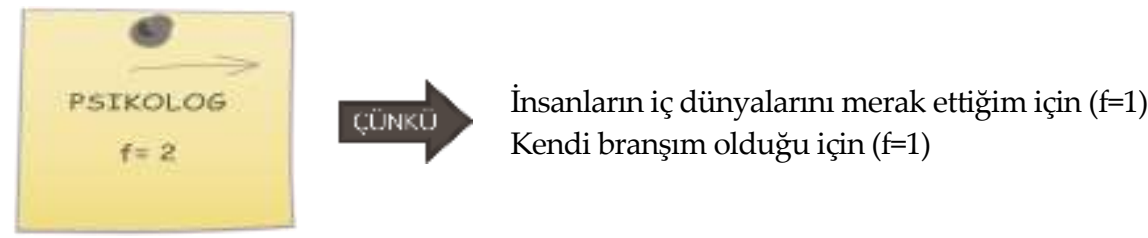

Şekil 10. Meslek seçimine ilişkin öğrenci görüşleri (Psikolog)

Psikolog olmak meslek tercihleri arasında ilk sırada yer alan öğrenciler bu mesleği seçme nedenleri olarak; insanların iç dünyalarını merak etmesi ve kendi branşı olmasını gerekçe olarak göstermiştir.

\section{Sonuç, Tartışma ve Öneriler}

Öğretmen olma niyetiyle pedagojik formasyon eğitimi alan öğrencilerin seçtikleri öğretmenlik mesleğine ilişkin görüşlerini belirlemek için yapılan bu çalışmada, öğrenciler öğretmenlik mesleğinin dışında sekiz farklı mesleği de kendilerine daha uygun olarak görmüşlerdir. Öğrencilerin çoğu ilk tercihlerinin yine öğretmenlikten yana olduğu yönünde görüş bildirirken bu görüşü sırasıyla doktor, sosyolog, sanatçı, hukukçu, mühendis, gazeteci, yazar ve psikolog izlemiştir. Bu durum öğrencilerin çoğunlukla doğru yerde olduğunu göstermektedir. Kendine uygun mesleği bulan öğrencilerin meslek yaşamlarında daha başarılı olacakları bilinen bir gerçektir. Dolayısıyla yeni nesil yetiştirme misyonunu yüklenen öğretmenlik, zoraki yapılacak bir meslek olmamalıdır. Öğretmenlik mesleğini kendi isteğiyle ve severek seçen adayların öğretmenliğe yönelik tutumlarının daha olumlu olduğu (Aslan ve Köksal Akyol, 2006; Aydın ve Yıldırım, 2007; Bozdoğan, Buldur ve Bursal, 2015; Eret Orhan ve Ok, 2014; Şahin, 2011; Ünal ve Şimşek, 2008; Üstüner, Demirtaş ve Cömert, 2009) diğer bazı araştırma sonuçlarıyla da ortaya konulmuştur. 
Öğretmenlik, meslek tercihleri arasında ilk sırada olan öğrenciler bu mesleği seçmede; bir şeyler öğretmenin verdiği hazzı yaşamak, meslek sevgisi, daha iyi bir nesil yetiştirmek, mesleğin kutsallığı, çocuk sevgisi, bütün meslek mensuplarını öğretmenlerin yetiştirmesi, hayalindeki meslek olduğu, başkalarının hayatın değiştirmek istediği, tatilinin çok olduğu, şartlarının iyi olduğu ve çocukları geleceğe hazırlamak gibi birçok nedeni sıralamışlardır. Öğretmenlik programlarında öğrenim gören öğrencilerin öğretmenlik mesleğini tercih etme sebeplerini belirlemeyi amaçlayan araştırmacılarda, öğretmenlik mesleğini kendi isteğiyle seçen birçok öğretmen adayının meslek tercih nedenlerinden birisi olarak geçmişte onlar üzerinde iz bırakan öğretmenleri örnek almaları olarak ifade edilmiştir (Montecinos ve Nielsen, 1997). Ayrıca öğretmenlik mesleği tercihiyle ilgili nedenlerin birçok faktörün devreye girmesiyle çok boyutlu olduğu sonucuna ulaşılmıştır. (Brookhart ve Freeman, 1992). Meslek tercihinde etkili olan diğer nedenler; bireysel özellikler, mesleğe duyulan ilgi, öğretmenliğin toplumsal statüsü, topluma faydalı olma isteği, tecrübeler, bireyler arası iletişim becerileri, ekonomik sebepler ve yaşama ait gereksinimler gibi farklı başlıklar altında incelenmiştir (Bursal ve Buldur, 2016).

Doktorluk meslek seçiminde ilk sırada olan öğrenciler bu mesleği seçme nedenleri olarak; insanlara yardım etmek, hayat kurtarmak, parasının çok olması ve sevdiği için bu mesleği yapmak istemesi görüşlerine yer vermişlerdir. Gerçekten de toplumumuzda doktorluk mesleği kazanılması ve eğitimi zor olan meslekler arasında olmasına rağmen popülaritesi devam etmektedir. Hukukçu olmak meslek tercihleri arasında ilk sırada olan öğrenciler bu mesleği seçme nedenleri olarak; adaleti sağlamak ve hayalindeki meslek olduğu görüşlerine yer vermişlerdir. Bireylerin kendini gerçekleştirebilmeleri için doğru meslek seçimleri önem taşımaktadır. Doğruluğu ve adaleti önceleyen kişilerin bu meslek grubunda yer alması toplumun geleceği açısından önem arz etmektedir. Sosyolog olmak meslek tercihleri arasında ilk sırada yer alan öğrenciler topluma ve toplumsal sorunlara duyarlı ve kendi branşı olmasını mesleği seçme gerekçesi olarak göstermişlerdir. Toplumsal duyarlılığın ön planda olduğu sosyolog mesleğini tercihleri arasında gösteren öğrencilerin bu mesleği yerine getirirken mesleki doyum yaşamaları ve mesleklerinde başarılı olmaları kaçınılmazdır. Sanatçı olmak meslek tercihleri arasında ilk sırada yer alan öğrenciler bu mesleği seçme nedenleri olarak; yete- 
nekli olmak, şarkı söylemeyi sevmek ve duygularını resim yaparak dile getirmek gibi gerekçeleri sıralamışlardır. Toplumuzda yeteneklerinin peşinden koşmak isteyen ancak erken yaşlarda aileler tarafından engellenen, farklı meslek gruplarına yönlendirilen çocukların olduğu bilinmektedir. Bunun yanında yeteneklerini meslek olarak değil de hobi olarak gösteren, ailesi istediği için başladığı okulunu yarım bırakıp yeteneklerine dönen bireylerin olduğunu söylemek mümkündür. Mühendis olmak meslek tercihleri arasında ilk sırada yer alan öğrenciler bu mesleği seçme nedenleri olarak; çocukluk hayalinin olması, çeşitli icatlarla uğraşmayı sevmesi ve teknolojiye ilgisinin olmasını gerekçe olarak göstermişlerdir. Geçmişte popülaritesi yüksek olan mesleklerden biri olarak görülen mühendislik günümüzde popülaritesi azalmaya yüz tutmuş mesleklerden biri durumuna gelmiştir. Öğrenciler içinde küçük bir grup da olsa tercihinde ilk sırada gazetecilik mesleği yer almaktadır. Gazeteci olmak meslek tercihleri arasında ilk sırada yer alan öğrenciler bu mesleği seçme nedenleri olarak; hayalindeki meslek olduğu, doğru ve gerçekleri dile getirmek istemesi bu mesleği seçmede gerekçe olarak belirtilmiştir. Yine öğrenciler içinde küçük bir grubun tercihlerinde ilk sırada yer alan yazarlık mesleği görülmektedir. Yazar olmak meslek tercihleri arasında ilk sırada yer alan öğrenciler bu mesleği seçme nedenleri olarak; hayalindeki meslek olduğu ve yazmayı sevmesini gerekçe olarak gösterilmiştir. Psikolog olmak meslek tercihleri arasında ilk sırada yer alan öğrenciler ise bu mesleği seçme nedenleri olarak; insanların iç dünyalarını merak etmesi ve kendi branşı olmasını gerekçe olarak gösterilmiştir.

Farklı bölümleri okuyan ve formasyon eğitimi alan öğrencilerin, meslek tercihlerinin nedenleriyle birlikte bilinmesi gelecek nesil öğretmenleri için umut verici olarak düşünülebilir. Öğrencilerin seçtikleri meslek hakkında olumlu duygular içinde olmaları onların başarılı bir şekilde mesleklerini yerine getirecekleri anlamına gelmektedir. Bu bağlamda formasyon öğrencilerine tercih ettikleri meslekteki görevlerini yerine getirme konusunda firsatlar verilmelidir. 


\title{
EXTENDED ABSTRACT
}

\section{Opinions on the Taking Pedagogical Formation Education Students of the Job Preferences}

\author{
Gönül Şener - Seda Gündüzlap \\ Munzur University
}

It is stated that teaching, which is one of the professions that has continued to be popular from the past to the present, has an important place among the reasons for being preferred as a profession because it has a critical role in the development of communities and the future of countries (Bishay, 1996; Ekici, 2015; Kızıltaş, Harmatov ve Sarıçam, 2012). In a study conducted, students are shown as the reason for choosing the teaching profession according to their own characteristics, loving them, believing that they will be happy by teaching and their parents' wishes (Şahin, 2011). Professional knowledge (field knowledge, field education knowledge, legislative knowledge), professional skills (planning, teaching education, creating learning environments, managing the teaching and learning process, measuring and evaluating), candidates who prefer the teaching profession. they must have values (national, spiritual and universal values, student approach, communication and cooperation, personal and professional development) (MEB, 2017). In order to reach these qualifications, pre-service teachers are required to have higher education.

The teaching profession in our country was a more respected profession until the recent past. However, in recent years, the social view of the teaching profession has started to decrease significantly. In addition, the appointment of some of the teachers appointed to the contract and their appointment after a certain period of time creates confusion in the appointment and employment of teachers. This situation remains an important problem for both contract teachers and prospective teachers (Şahin, 2011). In addition, the existence of the army of unemployed people who wait with the desire to become a teacher with the training training provided makes it important to reveal the perspective of those who choose the teaching profession. From this point, the 
aim of the research is to determine the opinions of the students who have received pedagogical training with the intention of becoming a teacher about the chosen teaching profession.

For the purpose of the study, it was shaped by the phenomenology pattern evaluated within the qualitative paradigm. Phenomenology helps us to investigate cases that we are aware of but cannot fully understand (Yildırım ve Şimşek, 2011). In the 2017-2018 academic year, 60 students who received training in the Department of Educational Sciences were determined as study groups. Collecting the study data was provided by the interview form. Content analysis method was used to analyze the data collected by considering the opinions of the teacher candidates due to the suitability of the research. The data obtained were analyzed in four stages as coding, determining themes, creating categories and placing them in appropriate themes, revealing and interpreting the findings. The formula developed by Miles and Heberman (1994) was used to ensure the reliability of the research. In this regard, the expert who was asked to evaluate has found ten statements suitable in a different category than the researchers. Thus, the reliability of the research with the calculations made; $\mathrm{P}=161 /(161+10) \mathrm{X} 100=94 \%$ and reliability was provided.

As a result of the research, by analyzing the data obtained in this study to determine the opinions of the students who have received pedagogical training education with the intention of being a teacher, the students saw eight different professions more suitable for them besides the teaching profession. While most of the students expressed their opinion that their first choices were for teaching again, this opinion was followed by a doctor, sociologist, artist, lawyer, engineer, journalist, writer and psychologist respectively.

Teaching, the students who are in the first place among their profession choices are choosing this profession; experiencing the pleasure of teaching something, love of profession, raising a better generation, holiness of the profession, love of children, educating all members of the profession, teachers are their dream professions, they want to change the lives of others, they have a great holiday, their conditions are good and their children They listed many reasons such as preparing for the future. The students who are in the first place in the choice of profession of medicine are the reasons for choosing this profession; They included opinions of helping people, saving lives, having a lot of money and wanting to do this profession because they love it. Being the 
lawyer, the students who rank first among their professional preferences are the reasons for choosing this profession; They provided opinions that it is the job of their dreams and to provide justice. Being the sociologist, the students, who rank first among their profession choices, are sensitive to the society and social problems and have shown their own branch as the reason for choosing the profession. Students who rank first among the professional preferences to be an artist are the reasons for choosing this profession; They listed the rationale for being talented, loving singing, and expressing their emotions by painting. Being the engineers, the students who rank first among their professional preferences were the reasons for choosing this profession; They have cited childhood dreams, love to deal with various inventions and interest in technology. Being a journalist, students who rank first among their job preferences are the reasons for choosing this profession; it is a dream job, the desire to express the truth and the truth is stated as a reason for choosing this profession. Being the author, the students who rank first among the profession preferences are the reasons for choosing this profession; it was shown as the reason for his dream job and to love writing. Being a psychologist, the students who rank first among the profession choices are the reasons for choosing this profession; It has been cited as the reason why people wonder their inner world and have their own branch.

The knowledge of students studying different departments and training in education together with the reasons of their professional preferences can be considered as promising for the next generation of teachers. Öğrencilerin seçtikleri meslek hakkında olumlu duygular içinde olmaları onların başarılı bir şekilde mesleklerini yerine getirecekleri anlamma gelmektedir. In this context, formation students should be given opportunities to fulfill their preferred profession.

\section{Kaynakça / References}

Arıkan Saltık, I., Avcl, U. ve Kaya, U. (2016). Mesleki bağlllık ve mesleği bırakma niyeti üzerinde etken faktörler olarak birey-meslek uyumu ve mesleğin sosyal statüsü: turizm sektöründe görgül bir araştırma. İ̧̧letme Araştırmalan Dergisi, $8(3), 42-63$.

Aslan, D. ve Köksal-Akyol, A. (2006). Okul öncesi öğretmen adaylarının öğretmenlik mesleğine yönelik tutumları ve mesleki benlik saygılarının incelenmesi. Çukurova Üniversitesi Sosyal Bilimler Enstitüsü Dergisi, 15(2), 51-60. 
Bishay, A. (1996). Teacher motivation and job satisfaction: A study employing the experience sampling method. Journal of Undergraduate Sciences, 3,147-154.

Blau, P. M., Gustad, J. W., Jessor, R., Parnes, H. S., ve Wilcock, R. C. (1956). Occupational choice: A conceptual framework. Industrial \& Labor Relations Review, 9(4), 531-543.

Bozdoğan, A. E., Aydın, D. ve Yıldırım, K. (2007). Öğretmen adaylarının öğretmenlik mesleğine ilişkin tutumları. Ahi Evran Üniversitesi Kırşehir Eğitim Fakültesi Dergisi (KEFAD), 8(2), 83-97.

Brookhart, S. M. and Freeman, D. J. (1992). Characteristics of entering teacher candidates. Review of Educational Research, 62(1), 37-60.

Buldur, S. ve Bursal, M. (2015). Fen bilgisi öğretmen adaylarının meslek tercih nedenlerinin etki düzeyleri ve mesleki geleceklerine yönelik beklentileri. Necatibey Ĕ̆itim Fakültesi Elektronik Fen ve Matematik Ĕ̆itimi Dergisi, 9(1), 81-107.

Bursal, M. ve Buldur, S. (2016). İköğretim öğretmen adaylarının meslek tercih nedenleri ve geleceklerine yönelik beklentileri: Karşılaştırmalı bir analiz. Abant $\dot{I} z-$ zet Baysal Üniversitesi Ĕ̆itim Fakültesi Dergisi, 16(2), 351-376.

Büyüköztürk, Ş., Kılıç Çakmak, E., Akgün, Ö.E., Karadeniz, Ş. ve Demirel, F. (2008). Bilimsel araştırma yöntemleri. PegemA: Ankara.

Carless, S.A. (2005). The influence of fit perceptions, equal opportunity policies, and social support network on pre-entry police officer career commitment and intentions to remain. Journal of Criminal Justice, 33, 341-352.

Chellen, H. and Nunkoo, R. (2010). Understanding students' commitment to employment in the tourism and hospitality industry. International Research Symposium in Service Management, 24-27 Ağustos, Mauritius.

Çakır, Ö. (2001). İşe bağlllık olgusu ve etkileyen faktörler. Ankara: Seçkin Yayıncılık.

Çelik, N. ve Üzmez, U. (2014). Üniversite öğrencilerinin meslek seçimini etkileyen faktörlerin değerlendirilmesi: çağrı merkezi hizmetleri örneği. Elektronik Mesleki Gelişim ve Araştırma Dergisi, 2(1), 94-105.

Edwards, J. R. (1991). Person-job fit: a conceptual integration, literature review, and methodological critique, International Review of Industrial and Organizational Psychology, 6, 283-357.

Ehrhart, K. H. and Makransky, G. (2007). Testing vocational interests and personality as predictors of person-vocation and person-job fit. Journal of Career Assessment, 15(2), 206-226.

Ekici, F. Y. (2015). Öğretmen adaylarının öğretmenlik mesleğine yönelik tutumlarının çeşitli değişkenler açısından incelenmesi (İstanbul Sabahattin Zaim Üniversitesi örneği). Uluslararası Sosyal Araştırmalar Dergisi, 7(35), 658-665. 
Elchardus, M. and Smits, W. (2008). The vanishing flexible: ambition, selfrealization and flexibility in the career perspectives of young belgian adults. Work, Employment and Society, 22(2), 243-262.

Erdoğan, İ. (1990). İşletmelerde kişi değerlemede psikoteknik. İstanbul: İstanbul Üniversitesi İsletme Fakültesi Yayın No: 243.

Eret Orhan, E. ve Ok, A. (2014). Öğretmenlik programlarını kimler tercih ediyor? Adayların giriş özellikleri ve öğretmenliğe yönelik tutumları. Hacettepe Üniversitesi Ĕ̆itim Fakültesi Dergisi, 29(4), 75-92.

Ersoy, A. F. (2016). Fenomenoloji. Saban, A. ve Ersoy, A. (Edt.), Eğitimde nitel araştırma desenleri. (ss. 51- 110). Ankara: Anı Yayınclik.

Ginzberg, E., Ginsburg, S. W., Axelrad, S. and Herma, J. L. (1951). Occupational choice, an approach to a general theory. New York: Columbia University Press.

Goulet, L. R. and Singh, P. (2002). Career commitment: a reexamination and an extension, Journal of Vocational Behavior, 61, 73-91.

Gündüz, H.B. (2005). Öğretmenlik mesleğine giriş. Ankara: Pegem A Yayınclık.

Gündüzalp, S. ve Şener, G. (2018). Öğretmen adaylarına göre lider öğretmen, Uluslararast Sosyal Araştırmalar Dergisi, 11(61), 668-680.

Hall, R.H. (1969). Occupations and the social structure. New Jersey Englewood Cliffs: Prentice-Hall, Inc.

Holland, J. L. (1959). A theory of vocational choice. Journal of Counseling Psychology, 6(1), 35-45.

Holland, J. L. (1997). Making vocational choices: A theory of vocational personalities and work environments (3. b.). Odessa, FL: Psychological Assessment Resources.

Hotaman, D. (2011). Eğitim fakülteleri kendi öğrencilerini seçebilir mi? Kuramsal Ĕ̆itim Bilim Dergisi, 4(1), 126-136.

İlhan, S. (2008). Yeni kapitalizm ve meslek olgusunun değisen anlamları üzerine. Dumlupinar Üniversitesi Sosyal Bilimler Dergisi, 21, 313-328.

Kıziltaş, E., Halmatov, M. ve Sarıçam, H. (2012). Okul öncesi öğretmenliği öğrencilerinin öğretmenlik mesleğine yönelik tutumları. Mehmet Akif Ersoy Üniversitesi Eğitim Fakültesi Dergisi, 23, 173-189.

Kuzgun, Y. (1985). Psikolojide insancıl yaklaşım. Ankara Üniversitesi Ĕ̆itim Bilimleri Fakültesi Dergisi, 18(1), 1-18.

Maslow, A. H. (1943). A theory of human motivation. Psychological Review, 50, 370396. 
MEB. (2017). Öğretmenlik mesleği genel yeterlikleri. http://oygm.meb.gov.tr/meb iys dosyalar/2017 12/11115355 YYRETMENLYK MESLEYY GENEL YETERLYKLERY.pdf 18 Mayıs 2020 tarihinde erişilmiştir.

Miles, M.B. and Huberman, A.M. (1994). Qualitative data analysis. London: Sage Publication.

Montecinos, C. and Nielsen, L. E. (1997). Gender and cohort differences in university students' decisions to become elementary teacher education majors. Journal of Teacher Education, 48, 47-54.

Polly, A. and Jimmy, S-C. (2002). The toolbox and the mirror: reflection and practice in progressive teacher education. Radical Teacher.

Robson, C. (2015). Bilimsel araştırma yöntemleri: Gerçek dünya araştırması. Ş. Çınkır ve N. Demirkasımoğlu (çev. ed.). Ankara: Anı Yayıncılık.

Roe, A. (1954). A new classification of occupations. Journal of Counseling Psychology, 1(4), 215-220.

Saks, A. M. and Ashforth, B. E. (1997). A longitudinal investigation of the relationships between job information sources, applicant perceptions of fit, and work outcomes. Personnel Psychology, 50, 395-426.

Sarkaya, T. ve Khorshid, L. (2009). Üniversite öğrencilerinin meslek seçimini etkileyen etmenlerin incelenmesi: üniversite öğrencilerinin meslek seçimi. Türk Ĕgitim Bilimleri Dergisi, 7(2),393-423.

Super, D.E. (1957). The psychology of careers. New York: Harper \& Brothers.

Şahin, İ. (2011). Öğretmen adaylarının öğretmen istihdamı ve mesleki geleceklerine ilişkin görüşleri, Kuram ve Uygulamada Eğitim Bilimleri, 11(3), 1167-1184.

Tiedeman, D.V. and O'Hara, R. (1963). Career development: Choice and adjustment. New York: College Entrance Examination Board.

Tokar, D.M., Fisher, A.R. and Subich, L.M. (1998). Personality and vocational behavior: a selective review of the literature, 1993-1997. Journal of Vocational Behavior, 53,115- 153.

Ünal, E. ve Şimşek, S. (2008). İlköğretim bölümü anabilim dallarında öğrenim gören öğretmen adaylarının mesleki benlik saygilarının çeşitli değişkenler açısından incelenmesi. Ilköğretim Online, 7(1), 41-52.

Ünsar, S., Akgün Kostak, M., Kurt, S. ve Özgül, E. (2011). Hemşirelerin kendini gerçekleştirme düzeyleri ve etkileyen etmenler. Dokuz Eylül Üniversitesi Hemşirelik Yüksekokulu Dergisi, 4 (1), 2-6. 
Üstüner, M., Demirtaş, H. ve Cömert, M. (2009). Öğretmen adaylarının öğretmenlik mesleğine yönelik tutumları (İnönü üniversitesi eğitim fakültesi örneği). Ĕğitim ve Bilim, 34(151), 140-155.

Wildes, V. J. (2004). Stigma in food service work: how it affects restaurant servers' intention to stay in the business or recommend a job to another. Tourism and Hospitality Research, 5(3), 213-233.

Yıldırım, A. ve Şimşek, H. (2011). Sosyal bilimlerde nitel araştırma yöntemleri. (8. baskı). Ankara: Seçkin Yayıncllik.

Yüksel Şahin, F. ve Hotaman, D. (2009). Vocational guidance aid in the orientation to teaching profession and teacher education, European Journal of Social Sciences, 10(1), 25-35.

\section{Kaynakça Bilgisi / Citation Information}

Şener, G. ve Gündüzalp, S. (2020). Pedagojik formasyon eğitimi alan öğrencilerin meslek tercihlerine ilişkin görüşleri. OPUS-Uluslararası Toplum Araştırmaları Dergisi, 16(28), 1054-1075. DOI: 10.26466/opus.677100 